\title{
EVALUASI DAN ANALISIS KOLAM RETENSI PENGENDALIAN BANJIR: STUDI KASUS KOLAM RETENSI BRIMOB KOTA PALEMBANG
}

\author{
Tri Fitriana ${ }^{1)}$, Taufik Ari Gunawan ${ }^{2)}$ dan Imroatul C Juliana ${ }^{3)}$ \\ 1) Program Studi Magister Teknik Sipil FT UNSRI, Graha Bukit Asam, Jl. Srijaya Negara Bukit Besar Palembang \\ 2,3) Jurusan Teknik Sipil dan Perencanaan FT UNSRI, Jl. Raya Prabumulih - Km.32 Indralaya, Ogan Ilir, Sumsel
}

\section{Abstract}

Brimob retention basin located within the Sekanak Sub-watershed system, which is a flood-prone point. Administratively, the Brimob retention basin area is a part of the Sub-district of Ilir Barat I. The research method used is computer modeling. The steps taken are: data collection, hydrological analysis, cross-sectional analysis, hydrological and hydraulic modeling using pumps. The Brimob retention basin can accommodate a volume of water up to $115,103.73 \mathrm{~m}^{3}$, up to an elevation of the embankment of $+4.30 \mathrm{~m}$. The magnitude of designed rainfall is $\mathrm{R} 2=118.78$ $\mathrm{mm}, \mathrm{R} 5=144.78 \mathrm{~mm}, \mathrm{R} 10=161.99 \mathrm{~mm}$ and $\mathrm{R} 25=183.73 \mathrm{~mm}$. The peak discharge of each return period is $\mathrm{Q} 2=6.30$ $\mathrm{m}^{3} / \mathrm{s}, \mathrm{Q} 5=7.67 \mathrm{~m}^{3} / \mathrm{s}, \mathrm{Q} 10=8.59 \mathrm{~m}^{3} / \mathrm{s}$ and Q25 $=9.74 \mathrm{~m}^{3} / \mathrm{s}$. To assess the effectiveness of pump operation, 2 (two) pumping capacities are simulated, namely: $2501 / \mathrm{sec}$ and $5001 / \mathrm{sec}$, each used 2 (two) pump units. The simulation used a pump with a capacity of $5001 / \mathrm{sec}$, and the amount of discharge (inflow) for each return period is as input. The conclusion is that the use of a pump with a capacity of $5001 / \mathrm{sec}$ can overcome excess water volume and avoid runoff and effective in dealing with the excess water in the Brimob retention basin.

Key Words: analysis, evaluation, hydraulic modeling, retention basin.

\section{PENDAHULUAN}

Potensi perubahan lahan semakin besar seiring pertambahan penduduk, dan memperbesar resiko terjadi banjir. Sehingga, diperlukan upaya pengendalian banjir untuk memperkecil resiko bahaya/kerugian akibat banjir (Kodoatie \& Sugiyanto, 2002). Pembangunan pesat yang terjadi di Kota Palembang, perumahan dan transportasi, mempengaruhi perubahan tata guna lahan.

Pada tanggal 13 November 2018, hujan dengan intensitas tinggi terjadi di kota Palembang dengan durasi waktu lebih dari 6 jam. Kondisi ini membuat sebagian besar wilayah Palembang mengalami genangan dengan beberapa variasi ketinggian dari 0,5 hingga 1,5 meter. Terjadi genangan yang cukup luas dengan durasi genangan yang cukup lama, akibat limpasan air yang tidak tertampung oleh drainase maupun kolam retensi. Durasi genangan bervariasi, dari jam-jaman bahkan berhari-hari.

Untuk mengurangi resiko terjadinya kerusakan dan kerugian akibat banjir, dibutuhkan pengendalian banjir yang dapat direalisasikan di lapangan. Kegiatannya mencakup: identifikasi lokasi banjir, perencanaan pengendalian banjir, penyusunan strategi pengendalian banjir, dan pelaksanaan program-program strategis. Kemudian dilakukan implementasi penanganan jangka pendek ataupun jangka panjang, untuk mendapatkan upaya penanganan yang efektif dengan dampak negatif yang seminimal mungkin.

Sebagai langkah untuk mengantisipasi meluasnya genangan/banjir dimasa yang akan datang, perlu dilakukan penelitian terhadap seberapa besar volume limpasan yang terjadi, sehingga dapat diketahui apakah volume limpasan tersebut masih berada pada ambang batas kapasitas sungai, drainase maupun kolam tampungan, agar dapat menjadi masukan dalam perencanaan sistem drainase maupun alternatif penanganan banjir, misalnya menggunakan tol air.

Kota Palembang, dengan sebagian wilayahnya berupa dataran rendah, dapat menggunakan konsep tol air dengan saluran tertutup dan pompa yang mempercepat jalannya air permukaan (runoff), yang ditampung melalui kolam dan didistribusikan pada DAS melalui saluran tertutup, didorong dengan pompa, dan diharapkan bekerja tanpa hambatan. Sehingga genangan/banjir yang terjadi tidak mengakibatkan dampak besar, terutama di kawasan yang mempunyai nilai strategis dan pengaruh penting terhadap kegiatan perekonomian masyarakat.

Berdasarkan fenomena banjir pada musim penghujan di sekitar Kolam Retensi Brimob, perlu ada kajian untuk meminimalisi dampak banjir yang terjadi. Kajian ini dilakukan dengan mengamati 
debit limpasan yang masuk, kemampuan kolam dalam menampung debit limpasan, dan solusi untuk meminimalkan limpasan saat terjadi hujan besar. Jika kapasitas tampung kolam retensi dan tidak cukup optimal, perlu ditambahkan bangunan pompa air untuk mengendalikan limpasan dan mempercepat (waktu) surut banjir (Gustini dkk., 2015).

\section{METODOLOGI}

Penelitian ini dilakukan pada kolam retensi Brimob yang termasuk dalam sistem sub DAS Sekanak. Sub DAS sistem Sekanak merupakan salah satu sub sistem yang ada di Kota Palembang. Kawasan kolam retensi Brimob secara administrasi masuk dalam Kecamatan Ilir Barat I. Kawasan tersebut merupakan daerah padat penduduk, dimana penggunaan lahan didominasi oleh pemukiman, kawasan niaga, komersial, perkantoran, dan ruang publik.

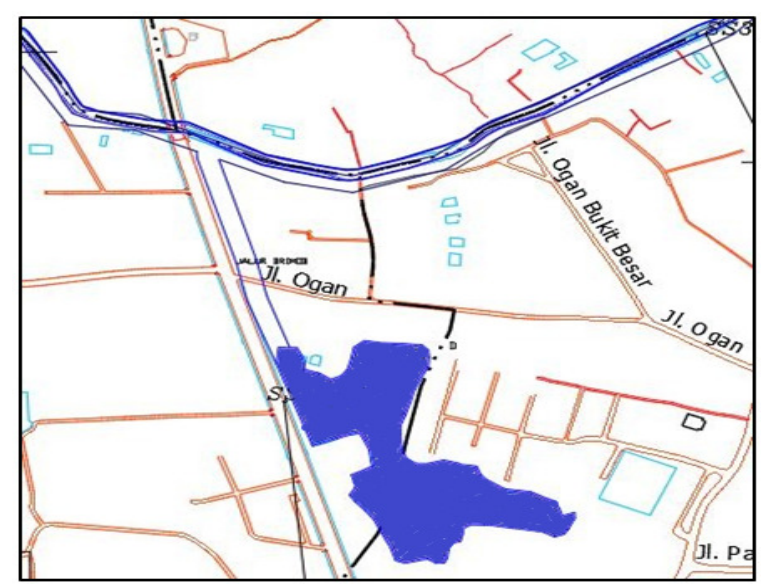

Gambar 1. Peta Lokasi Penelitian (Google Earth, 2018)

Data dikelompokkan menjadi dua, yaitu :

1) Data primer yang diperoleh dari survey lokasi di kolam retensi Brimob, yang meliputi: dokumentasi, topografi, dan kedalaman kolam retensi.

2) Data sekunder dari instansi terkait, meliputi: peta lokasi, data klimatologi, serta data bangunan pompa.

Sedangkan pengolahan data meliputi langkahlangkah, sbb:

1) Menghitung curah hujan wilayah,

2) Menghitung intensitas hujan,

3) Menentukan distribusi curah hujan yang paling tepat,

4) Melakukan uji kesesuaian distribusi,

5) Menghitung curah hujan rencana,

6) Menghitung debit banjir rencana di kolam retensi menggunakan HEC HMS,
7) Menganalisis penampang kapasitas kolam pada kondisi eksisting dan rencana,

8) Menganalisis dinamika aliran hidrolika pada kolam, dengan HEC-RAS 4.1 (Davis, 2008),

9) Menganalisis debit dengan beberapa alternatif pompa, panjang serta diameter pipa, sehingga dapat diestimasi penurunan elevasi muka air di kolam retensi, sehubungan dengan langkah pengendalian banjir.

\section{HASIL DAN PEMBAHASAN}

\subsection{Kondisi Kolam Retensi}

Secara umum sistem drainase Kota Palembang dibagi menjadi 21 (dua puluh satu) sub DAS sistem drainase. Sub DAS sistem Sekanak merupakan salah satu sub sistem di Kota Palembang. Penelitian ini dilakukan pada kolam retensi Brimob yang termasuk dalam sub sistem DAS Sekanak, dan merupakan titik rawan banjir.

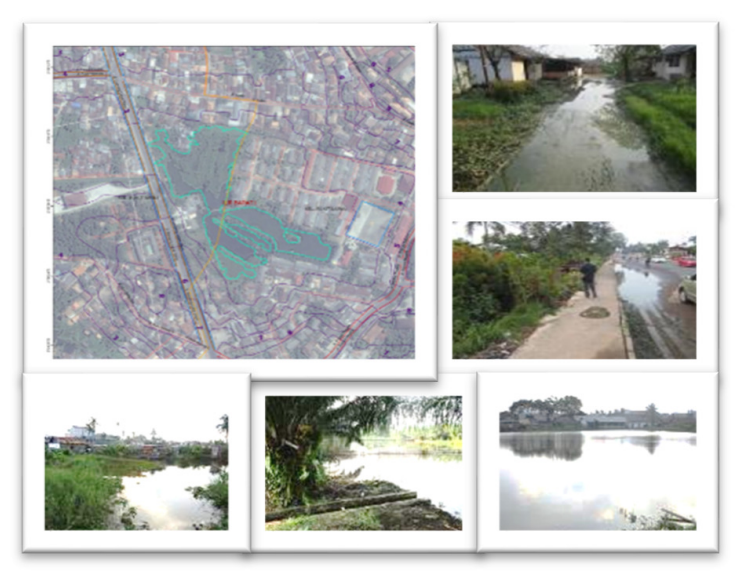

Gambar 2. Kondisi Kolam Brimob

\subsection{Parameter Hidrolis Kolam Brimob}

Proses penetuan batas kolam Brimob, berdasarkan pola aliran dan arah pengaliran, diperoleh dengan menganalisis data ketingian dengan memanfaatkan permodelan DEM. Penelitian ini menggunakan peta topografi dalam format 3 dimensi dengan ukuran resolusi grid $10 \mathrm{~m} \times 10 \mathrm{~m}$, yang dibuat dari data titik-titik tinggi. Resolusi $10 \mathrm{~m}$ x 10 m cukup baik untuk analisis banjir (Apirumanekul dan Mark, 2001). Dengan DEM, dilakukan analisis daerah tangkapan hujan sehingga diperoleh batas-batas daerah tangkapan hujan. Batas-batas daerah tangkapan hujan dan pola aliran yang diperoleh dari hasil analisis sesuai dengan pola aliran eksisting di lapangan. 
Cantilever $\mid$ Volume: 9 Nomor: 2 Oktober 2020 ISSN: 1907-4247 (Print) $\mid$ ISSN: 2477-4863 (Online) $\mid$ Website: http://cantilever.id Tri Fitriana., dkk. I Evaluasi dan Analisis Kolam Retensi Pengendali Banjir : Studi Kasus Kolam Retensi Brimob Kota Palembang

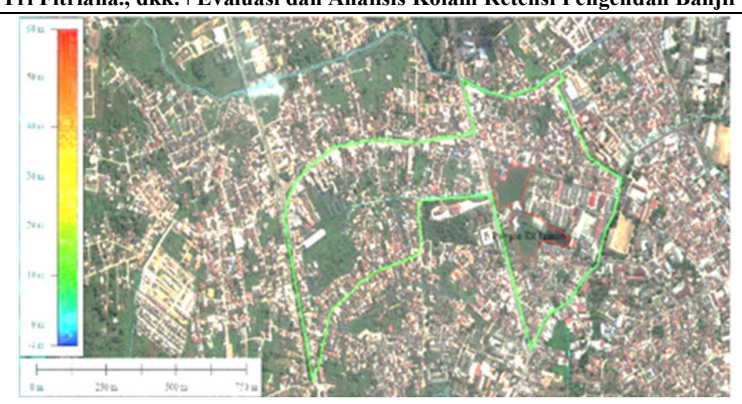

Gambar 3. Deleniasi Batas Daerah Tangkapan Air Terhadap Citra Google Earth

\subsubsection{Sistem Drainase Kolam Brimob}

Selain menerima aliran air hujan, kolam retensi Brimob juga menerima aliran limbah rumah tangga. Dari tinjauan lapangan, terdapat 21 saluran yang masuk ke kolam retensi Brimob, yang merupakan bagian dari drainase kota Palembang. Pada penelitian ini, debit limbah rumah tangga tidak diperhitungkan.

\subsubsection{Curah Hujan Rencana}

Dari hasil analisis Polygon Thiessen, DAS Sekanak dipengaruhi oleh Stasiun Kenten Klas II. Curah hujan harian maksimum tahun 2009-2018 tersaji dalam Tabel 1 (BPS, 2020). Selanjutnya, berdasarkan hasil analisis distribusi frekuensi, dilakukan uji kesesuaian distribusi (chi kuadrat dan klomogorov-Smirnov) untuk mengetahui distribusi yang paling sesuai terhadap sebaran data curah hujan yang ada. Dari hasil analisis, distribusi Gumbel merupakan yang paling sesuai, karena diterima oleh 2 metode uji kesesuaian distribusi, serta memiliki deviasi terkecil. Curah hujan harian maksimum rencana pada berbagai periode ulang, tersaji dalam Tabel 2. Prayoga dkk. (2013) merencanakan kolam retensi dan stasiun pompa pada Kali Semarang menggunakan debit banjir dengan periode ulang 10 tahun.

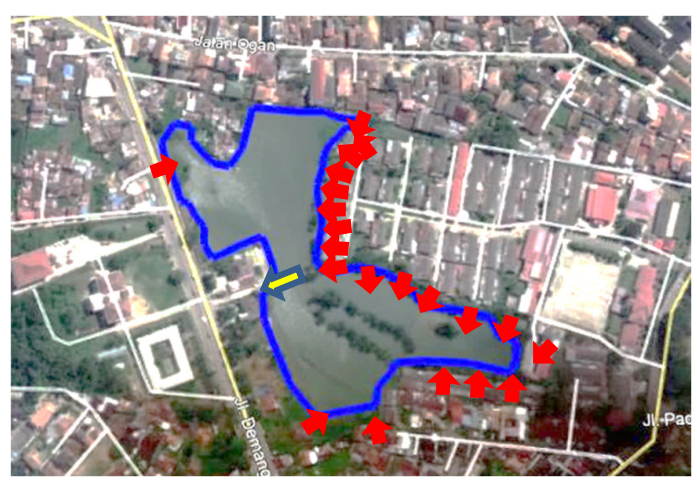

Gambar 4. Sistem Drainase Kolam Retensi Brimob

Tabel 1. Curah Hujan Harian Maksimum tahun 2009 sampai tahun 2018

\begin{tabular}{|c|c|c|c|c|c|c|c|c|c|c|c|c|}
\hline \multirow{2}{*}{ Tahun } & \multicolumn{12}{|c|}{ Tinggi Curah Hujan Harian (mm) } \\
\hline & Jan & Feb & Mar & Apr & May & Jun & Jul & Aug & Sep & Oct & Nov & Dec \\
\hline 2009 & 88.8 & 31.5 & 96.3 & 98.0 & 27.5 & 91.8 & 13.0 & 48.2 & 24.0 & 102.2 & 47.0 & 49.9 \\
\hline 2010 & 48.2 & 85.0 & 107.5 & 75.2 & 82.0 & 83.5 & 51.0 & 70.5 & 74.0 & 84.2 & 133.0 & 54.5 \\
\hline 2011 & 85.0 & 91.8 & 129.9 & 110.2 & 80.5 & 21.0 & 19.1 & 16.8 & 13.9 & 50.7 & 36.5 & 78.6 \\
\hline 2012 & 60.5 & 50.5 & 71.8 & 84.0 & 84.6 & 52.0 & 34.8 & 31.3 & 1.0 & 61.0 & 133.0 & 72.0 \\
\hline 2013 & 81.1 & 42.0 & 98.0 & 84.0 & 52.0 & 52.0 & 34.8 & 28.0 & 87.0 & 100.0 & 62.0 & 108.0 \\
\hline 2014 & 49.0 & 5.0 & 43.0 & 96.0 & 40.0 & 24.0 & 38.0 & 27.0 & 16.0 & 1.0 & 65.8 & 111.0 \\
\hline 2015 & 49.4 & 54.8 & 116.9 & 80.3 & 41.4 & 59.0 & 11.5 & 17.8 & 0.0 & 0.2 & 64.0 & 90.7 \\
\hline 2016 & 60.4 & 56.6 & 43.0 & 44.0 & 50.5 & 36.5 & 27.0 & 84.0 & 172.4 & 103.2 & 114.5 & 74.4 \\
\hline 2017 & 52.7 & 43.5 & 113.9 & 80.4 & 72.0 & 50.3 & 25.5 & 14.7 & 31.0 & 65.0 & 72.5 & 62.9 \\
\hline 2018 & 30.2 & 68.0 & 75.2 & 70.0 & 26.0 & 75.0 & 22.5 & 30.0 & 34.0 & 97.0 & 73.5 & 77.5 \\
\hline
\end{tabular}

Tabel 2 Curah Hujan Harian Maksimum Rencana Pada Berbagai Periode Ulang (Distribusi Gumbel)

\begin{tabular}{|r|c|}
\hline $\begin{array}{c}\text { Periode Ulang } \\
\text { (Tahun) }\end{array}$ & $\begin{array}{c}\text { Curah Hujan Harian Maksimum Rencana } \\
(\mathrm{mm})\end{array}$ \\
\hline 2 & 118.78 \\
\hline 5 & 144.78 \\
\hline 10 & 161.99 \\
\hline 50 & 183.73 \\
\hline
\end{tabular}

\subsubsection{Analisis Debit Banjir Rencana}

Intensitas Curah Hujan

Intensitas curah hujan jam-jaman dianalisis menggunakan metode Mononobe (Tabel 3) dan Alternate Block Method (Tabel 4 s.d Tabel 7). Rekapitulasi intensitas curah hujan jam-jaman untuk setiap periode ulang disajikan dalam Tabel 8 .

Tabel 3. Analisis Curah Hujan Jam-jaman dengan Metode Mononobe

\begin{tabular}{|c|c|c|c|c|c|c|}
\hline \multirow{2}{*}{$\begin{array}{c}\text { Tr } \\
(\text { Tahun })\end{array}$} & \multicolumn{5}{|c|}{ Intensitas Curah Hujan Menitan (mm/jam) } \\
\cline { 2 - 7 } & 60 & 120 & 180 & 240 & 300 & $3^{\prime} 60$ \\
\hline 2 & 41,18 & 25,94 & 19,80 & 16,34 & 14,08 & 12,47 \\
\hline 5 & 50,19 & 31,62 & 24,13 & 19,92 & 17,16 & 15,20 \\
\hline 10 & 56,16 & 35,38 & 27,00 & 22,29 & 19,21 & 17,01 \\
\hline 25 & 63,70 & 40,13 & 30,62 & 25,28 & 21,78 & 19,29 \\
\hline
\end{tabular}


Tri Fitriana., dkk. | Evaluasi dan Analisis Kolam Retensi Pengendali Banjir : Studi Kasus Kolam Retensi Brimob Kota Palembang

Cantilever | Volume : 9 | Nomor : 2 | Oktober 2020 | Hal. 89-95 | ISSN: 1907-4247 (Print) | ISSN: 2477-4863 (Online) | Website: http://cantilever.id

Tabel 4. Analisis Curah Hujan Jam-jaman dengan Metode ABM (Alternatif Block Method) 2 Tahun

\begin{tabular}{|c|c|c|c|c|c|c|c|}
\hline \multirow{2}{*}{$\begin{array}{c}\text { Td } \\
\text { (Jam) }\end{array}$} & \multirow{2}{*}{$\begin{array}{c}\text { Dt } \\
\text { (Jam) }\end{array}$} & \multirow{2}{*}{$\begin{array}{c}\text { It } \\
(\mathrm{mm} / \mathbf{j a m})\end{array}$} & \multirow{2}{*}{$\begin{array}{c}\text { It x Td } \\
(\mathrm{mm})\end{array}$} & \multirow{2}{*}{ Dp (mm) } & \multirow{2}{*}{ Pt (\%) } & \multicolumn{2}{|c|}{ Hyetograph } \\
\hline & & & & & & $(\%)$ & (mm) \\
\hline 1 & $0-1$ & 41.18 & 41.18 & 41.18 & $55 \%$ & $7 \%$ & 8.31 \\
\hline 2 & $1-2$ & 25.94 & 51.88 & 10.70 & $14 \%$ & $10 \%$ & 11.88 \\
\hline 3 & $2-3$ & 19.80 & 59.39 & 7.51 & $10 \%$ & $55 \%$ & 65.33 \\
\hline 4 & $3-4$ & 16.34 & 65.37 & 5.98 & $8 \%$ & $14 \%$ & 16.63 \\
\hline 5 & $4-5$ & 14.08 & 70.41 & 5.05 & $7 \%$ & $8 \%$ & 9.50 \\
\hline 6 & $5-6$ & 12.47 & 74.83 & 4.41 & $6 \%$ & $6 \%$ & 7.13 \\
\hline \multicolumn{4}{|c|}{ Jumlah } & 74.83 & $100 \%$ & $100 \%$ & 118.78 \\
\hline
\end{tabular}

Tabel 5. Analisis Curah Hujan Jam-jaman dengan Metode ABM (Alternatif Block Method) 5 Tahun

\begin{tabular}{|c|c|c|c|c|c|c|c|}
\hline \multirow{2}{*}{$\begin{array}{c}\text { Td } \\
\text { (Jam) }\end{array}$} & \multirow{2}{*}{$\begin{array}{c}\text { Dt } \\
\text { (Jam) }\end{array}$} & \multirow{2}{*}{$\begin{array}{c}\text { It } \\
(\mathrm{mm} / \mathrm{jam})\end{array}$} & \multirow{2}{*}{$\begin{array}{c}\text { It x Td } \\
(\mathrm{mm})\end{array}$} & \multirow{2}{*}{$\mathbf{D p}(\mathrm{mm})$} & \multirow{2}{*}{ Pt (\%) } & \multicolumn{2}{|c|}{ Hyetograph } \\
\hline & & & & & & $(\%)$ & (mm) \\
\hline 1 & $0-1$ & 50.19 & 50.19 & 50.19 & $55 \%$ & $7 \%$ & 10.13 \\
\hline 2 & $1-2$ & 31.62 & 63.24 & 13.05 & $14 \%$ & $10 \%$ & 14.48 \\
\hline 3 & $2-3$ & 24.13 & 72.39 & 9.15 & $10 \%$ & $55 \%$ & 79.63 \\
\hline 4 & $3-4$ & 19.92 & 79.67 & 7.29 & $8 \%$ & $14 \%$ & 20.27 \\
\hline 5 & $4-5$ & 17.16 & 85.82 & 6.15 & $7 \%$ & $8 \%$ & 11.58 \\
\hline 6 & $5-6$ & 15.20 & 91.20 & 5.38 & $6 \%$ & $6 \%$ & 8.69 \\
\hline \multicolumn{4}{|c|}{ Jumlah } & 91.20 & $100 \%$ & $100 \%$ & 144.78 \\
\hline
\end{tabular}

Tabel 6. Analisis Curah Hujan Jam-jaman dengan Metode ABM (Alternatif Block Method) 10 Tahun

\begin{tabular}{|c|c|c|c|c|c|c|c|}
\hline \multicolumn{8}{|l|}{$: 10$ ta } \\
\hline \multirow{2}{*}{$\begin{array}{c}\text { Td } \\
(\mathrm{Jam})\end{array}$} & \multirow{2}{*}{$\begin{array}{c}\text { Dt } \\
\text { (Jam) }\end{array}$} & \multirow{2}{*}{$\begin{array}{c}\text { It } \\
(\mathrm{mm} / \mathrm{jam})\end{array}$} & \multirow{2}{*}{$\begin{array}{c}\text { It x Td } \\
(\mathrm{mm})\end{array}$} & \multirow{2}{*}{ Dp (mm) } & \multirow{2}{*}{ Pt (\%) } & \multicolumn{2}{|c|}{ Hyetograph } \\
\hline & & & & & & $(\%)$ & $(\mathrm{mm})$ \\
\hline 1 & $0-1$ & 56.16 & 56.16 & 56.16 & $55 \%$ & $7 \%$ & 11.34 \\
\hline 2 & $1-2$ & 35.38 & 70.75 & 14.60 & $14 \%$ & $10 \%$ & 16.20 \\
\hline 3 & $2-3$ & 27.00 & 80.99 & 10.24 & $10 \%$ & $55 \%$ & 89.09 \\
\hline 4 & $3-4$ & 22.29 & 89.15 & 8.15 & $8 \%$ & $14 \%$ & 22.68 \\
\hline 5 & $4-5$ & 19.21 & 96.03 & 6.88 & $7 \%$ & $8 \%$ & 12.96 \\
\hline 6 & $5-6$ & 17.01 & 102.05 & 6.02 & $6 \%$ & $6 \%$ & 9.72 \\
\hline \multicolumn{4}{|c|}{ Jumlah } & 102.05 & $100 \%$ & $100 \%$ & 161.99 \\
\hline
\end{tabular}

Tabel 7. Analisis Curah Hujan Jam-jaman dengan Metode ABM (Alternatif Block Method) 25 Tahun

\begin{tabular}{|c|c|c|c|c|c|c|c|}
\hline \multirow{3}{*}{$\begin{array}{c}\text { Td } \\
\text { (Jam) }\end{array}$} & \multirow{3}{*}{$\begin{array}{c}\text { Dt } \\
\text { (Jam) }\end{array}$} & \multirow{3}{*}{$\begin{array}{c}\text { It } \\
(\mathrm{mm} / \mathrm{jam})\end{array}$} & \multirow{3}{*}{$\begin{array}{l}\text { It x Td } \\
(\mathrm{mm})\end{array}$} & \multirow{3}{*}{ Dp (mm) } & \multirow{3}{*}{ Pt (\%) } & \multirow{2}{*}{\multicolumn{2}{|c|}{ Hyetograph }} \\
\hline & & & & & & & \\
\hline & & & & & & $(\%)$ & $(\mathrm{mm})$ \\
\hline 1 & $0-1$ & 63.70 & 63.70 & 63.70 & $55 \%$ & $7 \%$ & 12.86 \\
\hline 2 & $1-2$ & 40.13 & 80.25 & 16.56 & $14 \%$ & $10 \%$ & 18.37 \\
\hline 3 & $2-3$ & 30.62 & 91.87 & 11.61 & $10 \%$ & $55 \%$ & 101.05 \\
\hline 4 & $3-4$ & 25.28 & 101.11 & 9.25 & $8 \%$ & $14 \%$ & 25.72 \\
\hline 5 & $4-5$ & 21.78 & 108.92 & 7.81 & $7 \%$ & $8 \%$ & 14.70 \\
\hline 6 & $5-6$ & 19.29 & 115.75 & 6.82 & $6 \%$ & $6 \%$ & 11.02 \\
\hline \multicolumn{4}{|c|}{ Jumlah } & 115.75 & $100 \%$ & $100 \%$ & 183.73 \\
\hline
\end{tabular}

Tabel 8. Rekapitulasi Intensitas Curah Hujan Jam-Jaman Rencana

\begin{tabular}{|c|r|r|r|r|}
\hline \multirow{2}{*}{ Jam Ke- } & \multicolumn{4}{|c|}{ Tinggi Curah Hujan Jam-Jaman (mm) Pada Periode Ulang } \\
\cline { 2 - 5 } & \multicolumn{1}{|c|}{ 2 Tahun } & \multicolumn{1}{c|}{ 5 Tahun } & 10 Tahun & \multicolumn{1}{c|}{ 25 Tahun } \\
\hline $\mathbf{1}$ & 8.01 & 9.77 & 10.93 & 12.39 \\
\hline $\mathbf{2}$ & 11.92 & 14.53 & 16.25 & 18.44 \\
\hline $\mathbf{3}$ & 65.37 & 79.67 & 89.15 & 101.11 \\
\hline $\mathbf{4}$ & 16.99 & 20.71 & 23.17 & 26.28 \\
\hline $\mathbf{5}$ & 9.49 & 11.56 & 12.94 & 14.68 \\
\hline $\mathbf{6}$ & 7.00 & 8.54 & 9.55 & 10.83 \\
\hline Jumlah & $\mathbf{1 1 8 . 7 8}$ & $\mathbf{1 4 4 . 7 8}$ & $\mathbf{1 6 1 . 9 9}$ & $\mathbf{1 8 3 . 7 3}$ \\
\hline
\end{tabular}

$\underline{\text { Koefisien Limpasan }}$

Koefisien limpasan (run off) ditentukan berdasarkan penggunaan lahan di daerah tangkapan. Peta tata guna lahan diperoleh dari peta garis hasil interprestasi citra foto dan perubahan Bappeda Kota Palembang. Jenis penggunaan lahan didominasi oleh pemukiman dengan luasan sebesar 27,67 Ha
$(61,50 \%)$, kebun sebesar 4,25 Ha (9,40\%), dan jalan sebesar $1,53 \mathrm{Ha}$ (3,40\%). Persentase luasan pemukiman dan jalan sangat berpotensi untuk menyebabkan debit limpasan yang besar. Persentase ruang terbuka hijau sebesar $1,84 \%$ masih jauh dari ideal, minimal $30 \%$.

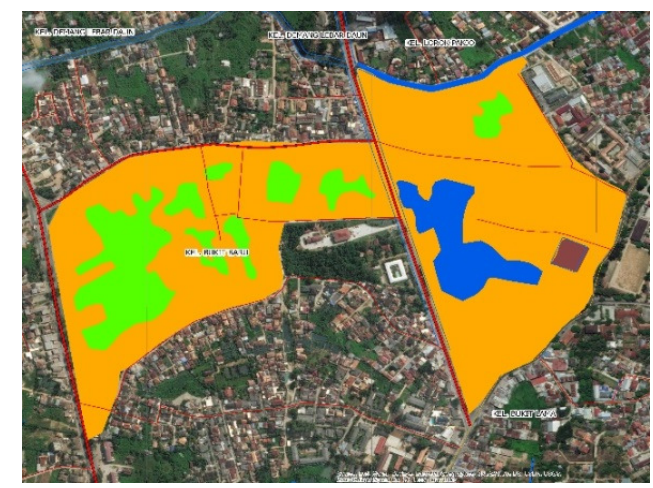

Gambar 5. Tata guna lahan wilayah kolam Brimob

\subsubsection{Debit Banjir Rencana}

Debit banjir rencana jam-jaman, dengan metoda Rational, untuk setiap periode ulangnya adalah $\mathrm{Q}_{2}=$ $6.30 \mathrm{~m}^{3} /$ det, $\mathrm{Q}_{5}=7,67 \mathrm{~m}^{3} / \mathrm{det}, \mathrm{Q}_{10}=8,59 \mathrm{~m}^{3} /$ det dan $\mathrm{Q}_{25}=9,74 \mathrm{~m}^{3} /$ det.

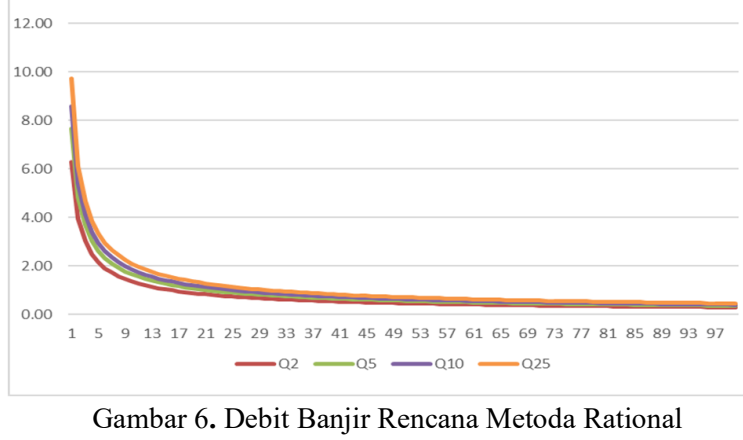

\subsection{Pemodelan Hidrologi dan Hidraulika}

\subsubsection{Kapasitas Kolam}

Untuk memperoleh luasan dan kapasitas kolam, dilakukan perhitungan penampang berdasarkan data profil memanjang dan melintang kolam. Kemudian dibuatkan skematisasi kolam sebagai persiapan input di dalam HEC-RAS (Gambar 7). Fungsi elevasi terhadap luasan, digunakan sebagai input dalam pemodelan hidrologi (Gambar 7 dan Tabel 9).

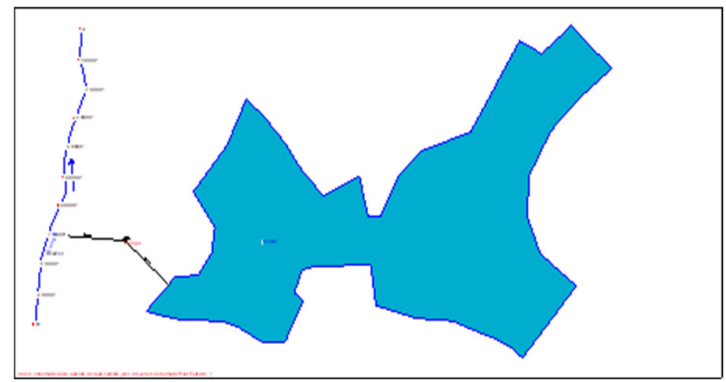

Gambar 7. Skematisasi Kolam dalam HEC-RAS 
Cantilever $\mid$ Volume: 9 Nomor: 2 Oktober 2020 ISSN: 1907-4247 (Print) $\mid$ ISSN: 2477-4863 (Online) $\mid$ Website: http://cantilever.id Tri Fitriana., dkk. I Evaluasi dan Analisis Kolam Retensi Pengendali Banjir : Studi Kasus Kolam Retensi Brimob Kota Palembang

Tabel 9. Hubungan antara Elevasi, dengan Luasan dan Volume

\begin{tabular}{|c|c|c|c|c|c|c|}
\hline $\begin{array}{l}\text { Elevasi } \\
(+\mathbf{m})\end{array}$ & $\begin{array}{c}\text { Beda } \\
\text { Tinggi } \\
(\mathbf{m})\end{array}$ & $\begin{array}{c}\text { Luas } \\
\text { Area } \\
(\mathbf{m} 2)\end{array}$ & $\begin{array}{c}\text { Luas Area } \\
(\mathbf{x ~ 1 0 0 0} \\
\mathbf{m} 2)\end{array}$ & $\begin{array}{c}\text { Volume } \\
(\mathbf{m 3})\end{array}$ & $\begin{array}{c}\text { Vol. Kum } \\
(\mathbf{m 3})\end{array}$ & $\begin{array}{c}\text { Vol. Kum } \\
(\mathbf{x 1 0 0 0} \\
\mathbf{m 3})\end{array}$ \\
\hline 0 & & 24373 & 24,373 & 0,00 & 0,00 & 0,00 \\
\hline 1 & 1 & 25479 & 25,479 & 24923,95 & 24923,95 & 24.92 \\
\hline 2 & 1 & 26594 & 26,594 & 26034,51 & 50958,47 & 50,96 \\
\hline 3 & 1 & 27719 & 27,719 & 27154,56 & 78113,02 & 78,11 \\
\hline 4 & 1 & 28854 & 28,854 & 28284,60 & 106397,63 & 106,40 \\
\hline 4.30 & 0,30 & 29187 & 29,197 & 8706,10 & 115103,73 & 115,10 \\
\hline
\end{tabular}

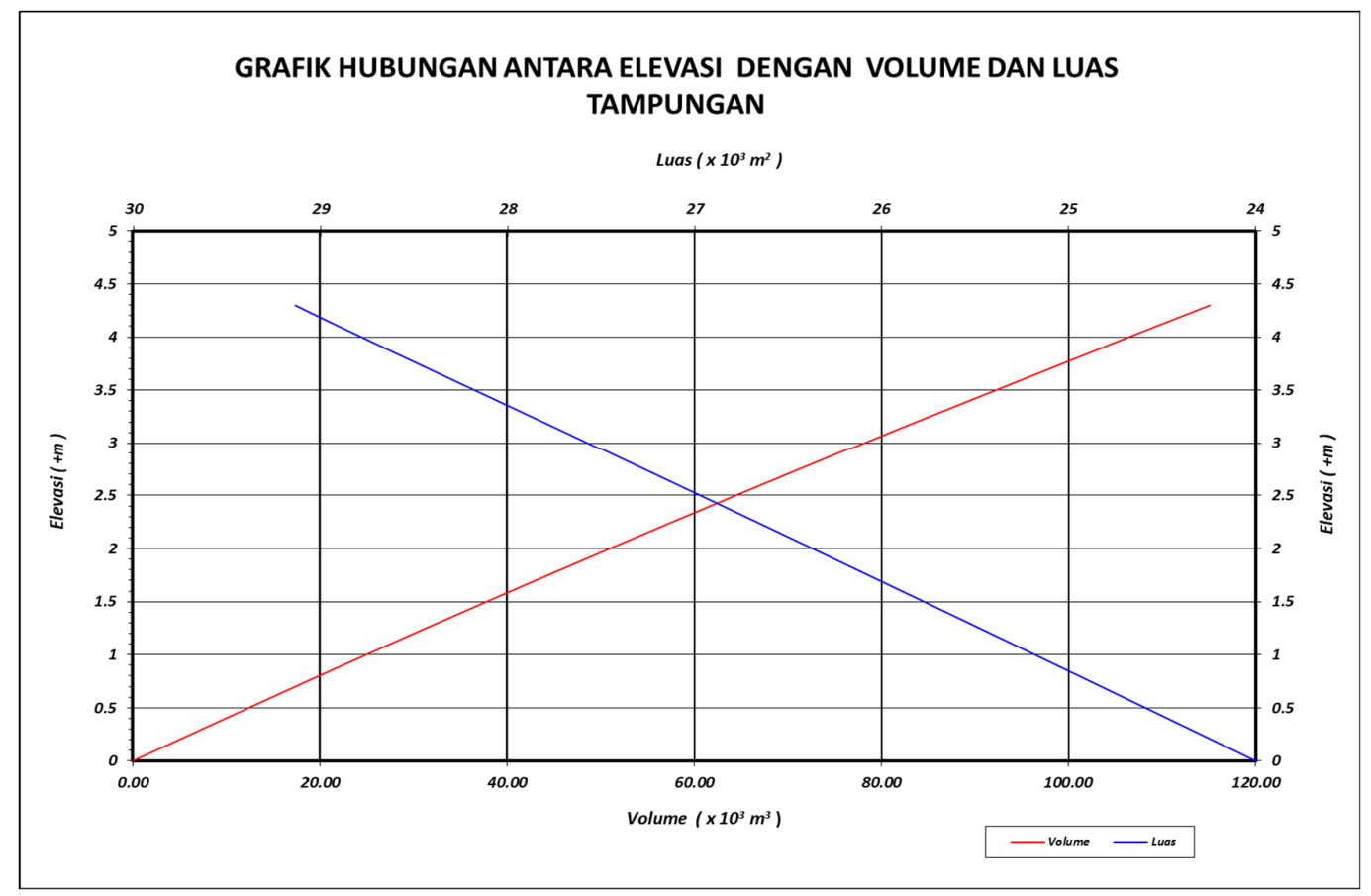

Gambar 8. Hubungan antara elevasi dengan volume

\subsubsection{Operasi Kolam dan Pompa}

Setelah mengetahui luasan dan volume tampungan pada setiap ketinggian elevasi muka air di kolam, dilakukan input data pada software HEC-RAS, sbb:

\section{a. Skenario 1: pompa kapasitas $250 \mathrm{lt} / \mathrm{sec}$}

Skenario dalam pengoperasian kolam, adalah:

1). Outlet kolam retensi disimulasikan dengan menggunakan 2 unit pompa, dengan kapasitas masing-masing pompa 250 liter/detik dan head sebesar 4,30 meter.

2). Pompa otomatis menyala apabila muka air di dalam kolam berada pada elevasi $+2,1$, dan otomatis mati apabila elevasi muka air berada pada elevasi $+1,10$.

b. Skenario 2: Pompa kapasitas $500 \mathrm{lt} / \mathrm{sec}$ Adapun skenario yang digunakan, sbb:

1) Outlet kolam retensi disimulasikan dengan menggunakan 2 unit pompa (dengan kapasitas masing-masing pompa 500 liter/detik dan head sebesar 4,30 meter).

2) Pompa otomatis menyala apabila muka air di dalam kolam berada pada elevasi $+2,1$, dan otomatis mati apabila elevasi muka air berada pada elevasi $+1,10$.

Pada pemodelan, dilakukan scenario pada setiap debit banjir (inflow) pada periode ulang 2 tahunan, 5 tahunan dan 10 tahunan (Tabel 10). Dari hasil simulasi, digunakan 2 unit pompa dengan kapasitas $250 \mathrm{lt} / \mathrm{sec}$ (Skenario 1) dan $500 \mathrm{lt} / \mathrm{sec}$ (Skenario 2).

Tabel 10. Tabel kala ulang tipelogi kota dan daerah pengaliran

\begin{tabular}{|l|c|c|c|c|}
\hline \multirow{2}{*}{ Tipologi Kota } & \multicolumn{4}{|c}{ Cathcment Area (Ha ) } \\
\cline { 2 - 5 } & $<10$ & $10-100$ & $100-500$ & $>500$ \\
\hline Kota Metropolitan & 2 thn & $2-5$ thn & $5-10$ thn & $10-25$ thn \\
\hline Kota Besar & 2 thn & $2-5$ thn & $2-5$ thn & $5-20$ thn \\
\hline Kota Sedang / Kecil & 2 thn & $2-5$ thn & $2-5$ thn & $5-10$ thn
\end{tabular}

sumber: PUPR (2018) 
Pada $\mathrm{Q}_{2}\left(6,30 \mathrm{~m}^{3} / \mathrm{det}\right)$, apabila diamati dalam 100 jam, kondisi pompa adalah:

- Pompa kapasitas $250 \mathrm{lt} / \mathrm{det}$, maka pompa mati pada jam ke $1-5$ (5 jam), dan mulai menyala pada jam ke $6-100$ (95 jam).

- Pompa kapasitas 500 lt/det, maka pompa mati pada jam ke $1-5$ (5 jam), dan mulai menyala pada jam ke 6 - 46 (40 jam), pompa mati kembali pada jam ke 47 - 63 (16 jam), pompa menyala kembali pada jam ke 64 - 74 (10 jam), pompa mati kembali pada jam ke 75 - 98 (23 jam), kemudian menyala kembali pada jam ke $99-100$ ( 2 jam $)$.

Pada $\mathrm{Q}_{5}$ (7,67 m3/det), jika diamati dalam 100 jam, kondisi pompa adalah:

1) Pompa kapasitas $250 \mathrm{lt} / \mathrm{det}$, maka pompa mati pada jam ke $1-4$ (4 jam), dan mulai menyala pada jam ke 5 - 100 (96 jam).

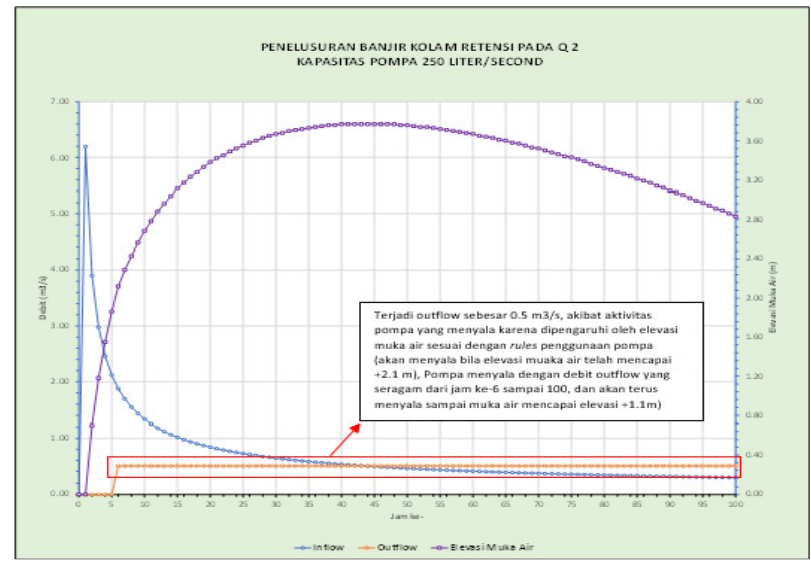

(a)
2) Pompa kapasitas 500 lt/det, maka pompa mati pada jam ke 1 - 4 (4 jam), dan mulai menyala pada jam ke 5 - 60 (55 jam), pompa mati kembali pada jam ke $61-77$ (17 jam), pompa menyala kembali pada jam ke 78 - 89 (11 jam), kemudian mati kembali pada jam ke $90-100$ (10 jam).

Pada $\mathrm{Q}_{10}\left(8,59 \mathrm{~m}^{3} / \mathrm{det}\right)$, jika diamati dalam $100 \mathrm{jam}$, kondisi pompa adalah:

1) Pompa kapasitas $250 \mathrm{lt} / \mathrm{det}$, maka pompa mati pada jam ke $1-4$ (4 jam), dan mulai menyala pada jam ke 5 - 100 (96 jam).

2) Pompa kapasitas $500 \mathrm{lt} / \mathrm{det}$, maka pompa mati pada jam ke $1-4$ (4 jam), dan mulai menyala pada jam ke 5 - 72 (67 jam), pompa mati kembali pada jam ke 73 - 89 (16 jam), kemudian pompa menyala kembali pada jam ke $90-100$ (10 jam).

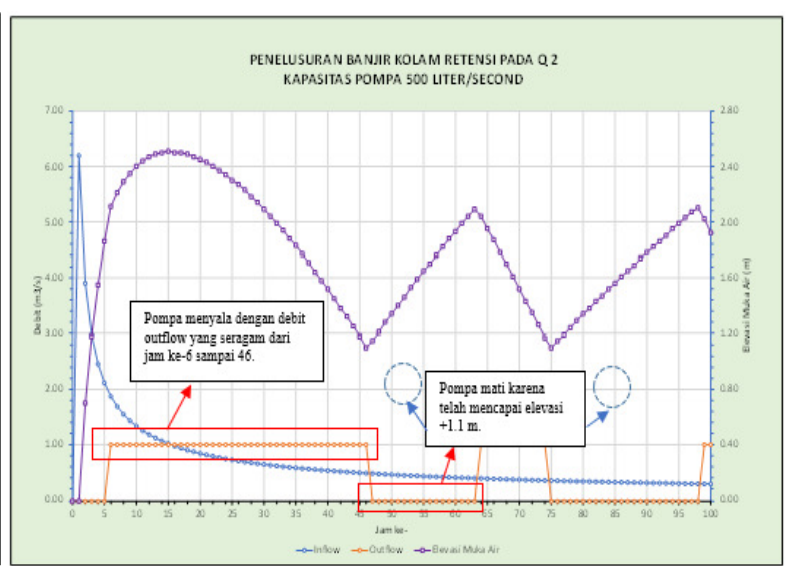

(b)

Gambar 9. Penelusuran banjir pada kolam retensi (Q2 tahun) dengan (a) kapasitas pompa 250 lt/det (b). kapasitas pompa 500 1t/det.

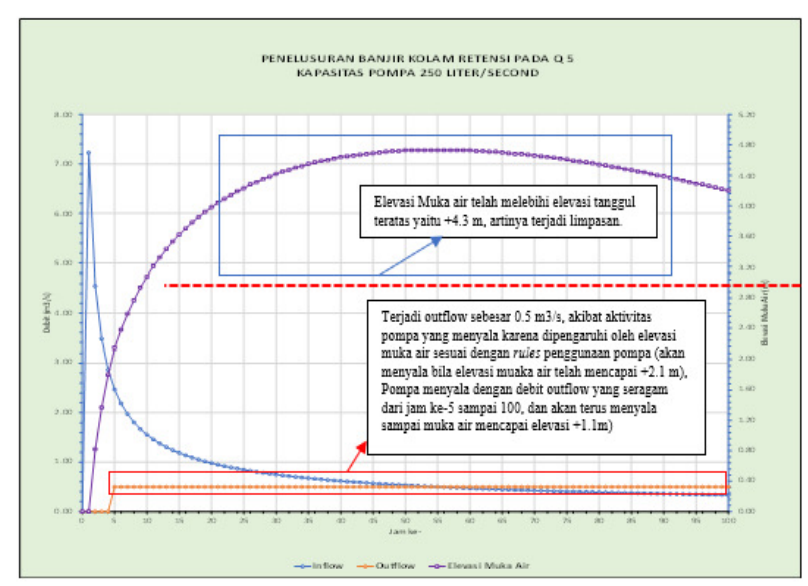

(a)

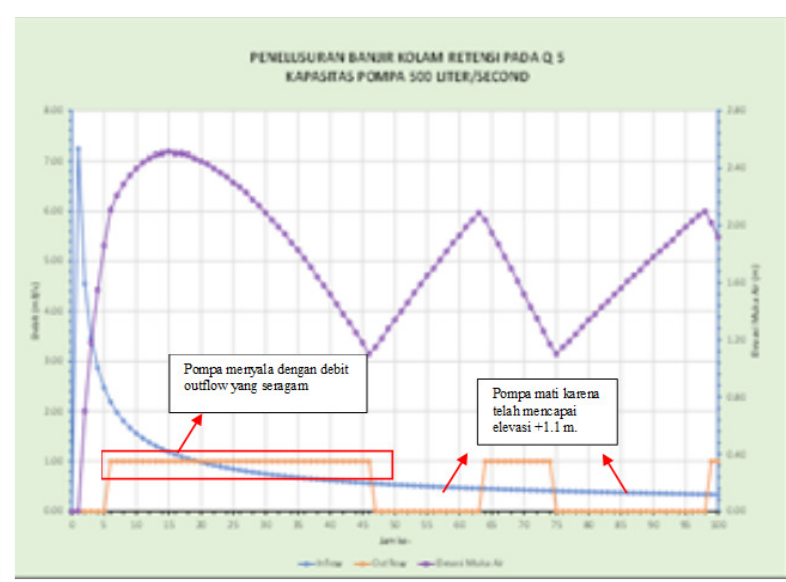

(b)

Gambar 10. Penelusuran banjir pada kolam retensi (Q5 tahun) dengan (a) kapasitas pompa 250 lt/det (b). kapasitas pompa 500 lt/det. 


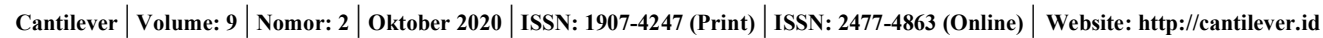

Tri Fitriana., dkk. I Evaluasi dan Analisis Kolam Retensi Pengendali Banjir : Studi Kasus Kolam Retensi Brimob Kota Palembang

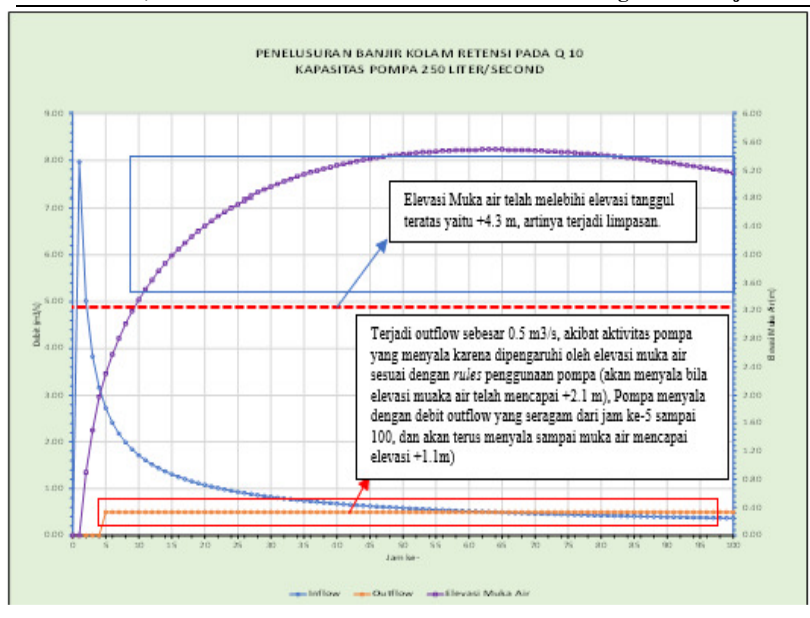

(a)

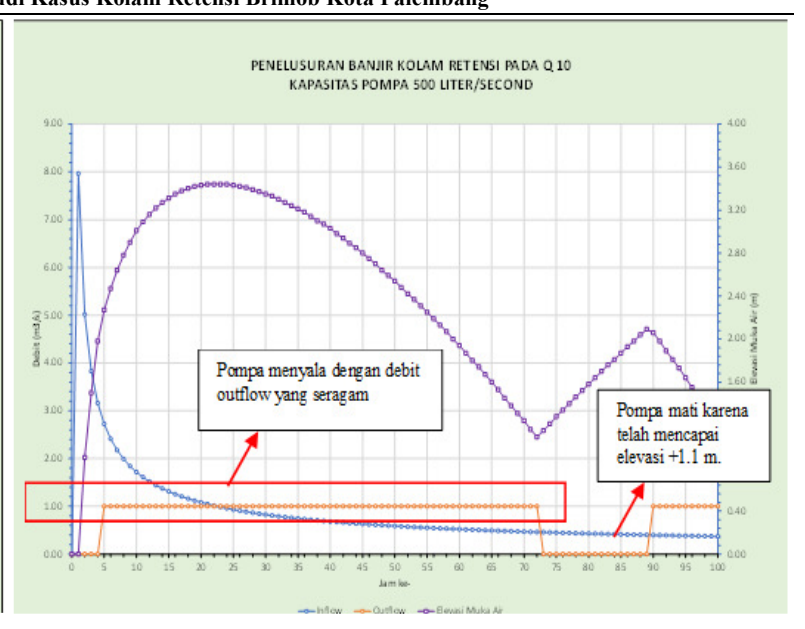

(b)

Gambar 11. Penelusuran banjir pada kolam retensi (Q10 tahun) dengan (a) kap. pompa 250 lt/det (b). Kap. pompa 500 lt/det

Dilihat dari hasil simulasi dengan menggunakan kapasitas pompa 500 lt/det, berdasarkan debit inflow untuk setiap periode ulang yang digunakan, diperkirakan tidak akan terjadi limpasan. Sehingga, direkomendasikan penggunaan pompa dengan kapasitas 500 liter/det.

Penggunaan pompa dengan kapasitas 250 liter/det dan 500 liter/det memiliki kelebihan dan kekurangan dalam pengoperasiannya. Khususnya dalam penggunaan tenaga manusia sebagai pengoperasi, dan bahan bakar untuk menyalakan pompa. Sehingga perlu dilakukan kajian juga dari segi biaya untuk mengoperasikan pompa, baik dengan kapasitas 250 liter/det maupun 500 liter/det.

\section{KESIMPULAN}

1. Terdapat 21 saluran yang masuk ke kolam retensi Brimob, yang merupakan bagian dari sistem drainase Kota Palembang. Air buangan dialirkan menuju sungai Sekanak.

2. Kolam retensi Brimob mampu menampung volume air hingga $115.103,73 \mathrm{~m}^{3}$, pada elevasi tanggul $+4,30 \mathrm{mdpl}$.

3. Curah hujan rencana, adalah: $\mathrm{R}_{2}=118,78 \mathrm{~mm}$, $\mathrm{R}_{5}=144,78 \mathrm{~mm}, \mathrm{R}_{10}=161,99 \mathrm{~mm}$ dan $\mathrm{R}_{25}=$ $183,73 \mathrm{~mm}$. Curah hujan rencana menjadi masukan dalam memprediksikan limpasan ke dalam kolam. Debit puncak untuk setiap periode ulang, adalah: $\mathrm{Q}_{2}=6,30 \mathrm{~m}^{3} / \mathrm{det}, \mathrm{Q}_{5}=$ $7,67 \mathrm{~m}^{3} /$ det, $\mathrm{Q}_{10}=8,59 \mathrm{~m}^{3} /$ det, dan $\mathrm{Q}_{25}=9,74$ $\mathrm{m}^{3} /$ det.

4. Dibuat dua skenario operasi pompa, masingmasing dengan (dua unit) pompa kapasitas 250 liter/det dan 500 liter/det.
5. Dari hasil simulasi dengan dua unit pompa kapasitas 250 liter/det, dan dengan dua unit pompa kapasitas 500 liter/det, diperkirakan tidak terjadi limpasan pada debit inflow desain untuk setiap periode ulang (2, 5, dan 10 tahun).

\section{UCAPAN TERIMA KASIH}

Ucapan terima kasih disampaikan kepada Dosen Universitas Sriwijaya atas arahan, bimbingan dan kerjasama yang baik dalam penelitian ini.

\section{DAFTAR PUSTAKA}

Anonim. 2010. Program Komputer HEC-HMS Versi 4.2. US Army Corps of Engineers.

Apirumanekul, C. \& Mark, O. (2001). Modelling of Urban Flooding in Dhaka City. 4th DHI Software Conference. DOI: 10.1061/40583(275)32.

BPS Kota Palembang. (2020). Kota Palembang dalam Angka Tahun 2020. Palembang: BPS Kota Palembang.

Davis. 2008. Program Komputer HEC-RAS Versi 4.1. US Army Corps of Engineers.

Gustini M., Susanto, R. H., \& Saleh, E. (2015). Skenario Pengendalian Banjir Kawasan OPI Jakabaring Masa Kini dan Akan Datang. INFO TEKNIK, 16(2), 171-184.

Kodoatie, R. J \& Sugiyanto. (2002). Banjir (Beberapa Penyebab dan Metode Pengendalian Banjir dalam Perspektif Lingkungan). Yogyakarta: Pustaka Belajar.

Prayoga, M. D., Tegar, R. W. A., Sangkawati, S., \& Sugiyanto. (2013). Perencanaan Kolam Retensi dan Stasiun Pompa pada Sistem Drainase Kali Semarang. Jurnal Karya Teknik Sipil S1 Undip, 2(2), 209-218

PUPR (2018). Perencanaan Sistem Folder dan Kolam Retensi. PUPR: Diklat Teknis. 